constituents recognized as "nonself" in the event of a Shigella infection.

Gabriel Dinari,* Thomas L. Hale, Smiley W. Austin, Samuel B. Formal Department of Enteric Infections, Walter Reed Army Institute of Research, Washington, D.C.

* Present address: Pediatric Gastroenterology Unit, Beilinson Medical Center, Petah-Tiqva, Israel.

\section{References}

1. Hale TL, Oaks EV, Formal SB. Identification and antigenic characterization of virulence-associated, plasmid-coded proteins of Shigella spp. and enteroinvasive Escherichia coli. Infect Immun 1985;50:620-9

2. Oaks EV, Hale TL, Formal SB. Serum immune response to Shigella protein antigens in thesus monkeys and humans infected with Shigella spp. Infect Immun 1986;53:57-63

3. Hale TL, Sansonetti PJ, Schad PA, Austin S, Formal SB. Characterization of virulence plasmids and plasmidassociated outer membrane proteins in Shigella flexneri, Shigella sonnei, and Escherichia coli. Infect Immun 1983;40:340-50
4. Sansonetti PJ, Kopecko DJ, Formal SB. Shigella sonnei plasmids: evidence that a large plasmid is necessary for virulence. Infect Immun 1981;34:75-83

5. Formal SB, Hale TL, Kapfer C, Cogan JP, Snoy PJ, Chung $\mathrm{R}$, Wingfield ME, Elisberg BL, Baron LS. Oral vaccination of monkeys with an invasive Escherichia coli $\mathrm{K}-12$ hybrid expressing Shigella flexneri 2a somatic antigen. Infect Immun 1984;46:465-9

6. Sansonetti PJ, Kopecko DJ, Formal SB. Involvement of a plasmid in the invasive ability of Shigella flexneri. Infect Immun 1982;35:852-60

7. Autrup $\mathbf{H}$. Explant culture of human colon. Methods Cell Biol 1980;21(Suppl B):385-401

8. Shorter RG, Tomasi TB Jr. Gut immune mechanisms. Adv Intern Med 1982;27:247-80

9. Svennerholm A-M, Holmgren J. Immunoglobulin and specific-antibody synthesis in vitro by enteral and nonenteral lymphoid tissues after subcutaneous cholera immunization. Infect Immun 1977;15:360-9

10. Hale TL, Oaks EV, Formal SB, Dinari G, Escheverria P. Immune response to Shigella infections and to Shigella vaccines. In: Brown F, Chanock RM, Lerner RA, eds. Vaccines86. New approaches to immunization. Cold Spring Harbor, NY: Cold Spring Harbor Laboratory, 1986:181-5

THE JOURNAL OF INFECTIOUS DISEASES - VOL. 155, NO. 5 - MAY 1987

(C) 1987 by The University of Chicago. All rights reserved. $0022-1899 / 87 / 5505-0035 \$ 01.00$

\title{
Monosaccharide Inhibition of Staphylococcus aureus Adherence to Human Solid-Phase Fibronectin
}

Fibronectin is a high-molecular-weight glycoprotein found in plasma and various body fluids or occurring as a major cell-surface glycoprotein synthesized by a variety of cells. Two polypeptide chains are organized into structural domains having specific binding properties for different molecules and cells. Staphylococci and streptococci bind to the amino-terminal region of fibronectin $[1,2]$. Fibronectin promotes adherence of staphylococcal cells to polymethylmethacrylate (a material widely used in prosthetic devices) in vitro [3] and in vivo $[4,5]$. There are conflicting data regarding the chemical structure of bacterial receptors for fibronectin $[6,7]$. In addition to proteins, various forms of carbohydrate-containing mac-

Received for publication 2 May 1986, and in revised form 1 October 1986.

This work was supported by grant 3.990 .084 from the Swiss National Research Foundation.

We thank Drs. Pierre Vaudaux, Daniel Lew, and Susanne Suter for many helpful discussions and suggestions.

Please address requests for reprints to Dr. Francis A. Waldvogel, Division of Infectious Diseases, Hôpital Cantonal Universitaire, $\mathrm{CH}-1211$ Geneva 4, Switzerland. romolecules are present on the surface of $S$. aureus-cell wall peptidoglycan and the teichoic acids - whereas capsule and slime are components of an exopolysaccharide matrix [8] that surrounds microcolonies adsorbed onto a biomaterial. This exopolysaccharide matrix is thought to have a protective function against antibacterial agents and host defense mechanisms [8]. We designed our study to (I) develop a suitable system allowing serial and quantitative tests of adherence, (2) define the role of preadsorbed macromolecules (such as collagen and human fibronectin) in the adherence of $S$. aureus strain Wood 46 to a plastic surface, and (3) evaluate the role of sugar moieties in the adherence of $S$. aureus to surface-bound fibronectin.

\section{Materials and Methods}

The bacterial strain used in this study was Staphylococcus aureus Wood 46, which is devoid of protein A. Fibronectin-depleted serum and fibronectin from human plasma, purified by affinity chromatography on gelatinSepharose ${ }^{(}$, were provided by J. J. Morgenthaler (Swiss Red Cross, Bern, Switzerland). All chemicals were of the best analytical grade commercially available. 


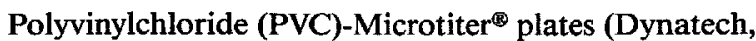
Kloten, Switzerland) were coated with fibronectin or collagen. Fibronectin or collagen $(50 \mu \mathrm{l})$ at protein concentrations of $50 \mu \mathrm{g} / \mathrm{ml}$ or $10 \mu \mathrm{g} / \mathrm{ml}$, respectively, in Salt $/ P_{i}$ buffer (16.3 mM Na $\mathrm{maO}_{4} \cdot 2 \mathrm{H}_{2} \mathrm{O}, 1.5 \mathrm{~m} M \mathrm{KH}_{2} \mathrm{PO}_{4}, 137$ $\mathrm{m} M \mathrm{NaCl}$, and $2.7 \mathrm{mM} \mathrm{KCl}$; $\mathrm{pH} 7.4$ ) were added to the wells. The plates were incubated overnight at $4 \mathrm{C}$ and then washed four times with $300 \mu l$ of Salt/Piffer. Nonspecific binding sites on the plastic were blocked by adding $50 \mu \mathrm{l}$ of $1 \%$ bovine serum albumin in the same buffer as above and incubating the plates for $1 \mathrm{hr}$ at $37 \mathrm{C}$. After the wells were rinsed four times with $300 \mu$ l of buffer, the plates were used in the adherence assay.

Serial dilutions containing $3-400 \mu \mathrm{g}$ of native or heatdenatured (100 C for $3 \mathrm{~min}$ ) fibronectin and $10^{3}-10^{5} \mathrm{cpm}$ of ${ }^{125}$ I-labeled fibronectin were added to the microtiter plates, which were then incubated overnight at $4 \mathrm{C}$. The wells were washed with four times with $300 \mu l$ of Salt $/ P_{i}$ buffer, cut off, and counted for bound radioactivity.

Staphylococcus aureus Wood 46 was labeled with [methyl ${ }^{3} \mathbf{H}$ ] thymidine [3] under two different experimental conditions. ( $I$ ) One hundred microliters of an overnight, washed culture of $S$. aureus Wood 46 in $4.4 \mathrm{ml}$ of MuellerHinton broth was incubated with $200 \mu \mathrm{Ci}$ of $\left[{ }^{3} \mathrm{H}\right]$ thymidine for $3 \mathrm{hr}$ at $37 \mathrm{C}$. The suspension was centrifuged at $3,000 \mathrm{~g}$ for $10 \mathrm{~min}$. The pelleted bacteria were washed twice with Salt $/ \mathrm{P}_{\mathrm{i}}$ buffer and finally suspended in $5.5 \mathrm{ml}$ of the same buffer. (2) Four hundred microliters of MuellerHinton broth was replaced by the same volume of guinea pig serum to test the effect of serum proteins on the adherence of $S$. aureus to surface-bound fibronectin.

For the adherence assay, $5 \times 10^{6}$ cells in $100 \mu \mathrm{l}$ of Salt/ $\mathrm{P}_{\mathrm{i}}$ buffer were added to each well of the PVCmultiwell plates that had been precoated with fibronectin. In the competition experiments the sugars used as inhibitors were included in the buffer and added to the microtiter plates $\mathbf{3 0}$ min before the cells were added. After incubation for $1 \mathrm{hr}$ at $37 \mathrm{C}$, the adherence medium was removed and the unattached cells were washed off by rinsing the wells four times with $300 \mu l$ of buffer. Radioactivity of the attached bacteria was solubilized by incubating the microtiter plates for $1 \mathrm{hr}$ at $37 \mathrm{C}$ with $50 \mu \mathrm{l}$ of trypsin $\left(0.2 \mathrm{mg} / \mathrm{ml}\right.$ of Salt $/ P_{i}$ buffer $)$. Similar results were obtained when the wells were cut off from the plates and directly counted for attached radioactivity (data not shown). When bacteria were tested for adherence to the collagen-coated PVC wells, we examined three growth conditions: (I) $8.5 \%$ serum-containing medium, (2) $8.5 \%$ fibronectin-depleted, serum-containing medium, and (3) medium without serum.

\section{Results}

The adherence of $S$. aureus Wood 46 to PVC microtiter plates was a function of the fibronectin bound to the sur-

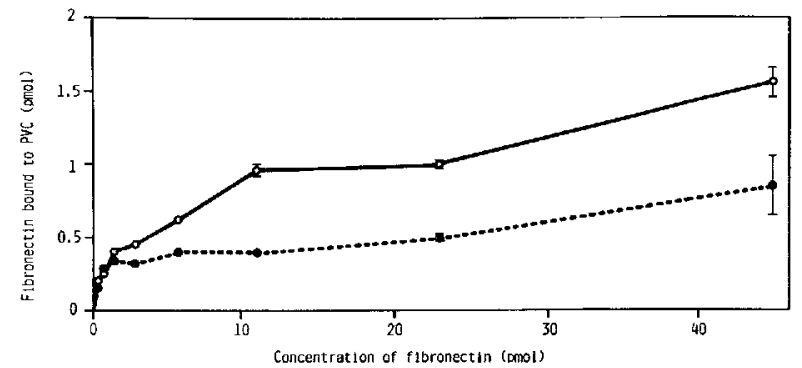

Figure 1. Adsorption of native $(O)$ and heat-denatured (e) human fibronectin to PVC microtiter plates. The results are the means $( \pm S D)$ of three experiments.

face. Maximum adherence of bacteria was observed at a concentration of $50 \mu \mathrm{g}$ of fibronectin $/ \mathrm{ml}(5.7 \mathrm{pmol}$ of free fibronectin). Bacteria grown in either serum-containing or serum-free medium showed identical binding to fibronectin-coated wells. Native as well as heat-denatured fibronectin bound to PVC in a dose-dependent, saturable manner (figure 1). However, denatured fibronectin did not promote adherence of $S$. aureus Wood 46.

In a control experiment, $1.9 \times 10^{5} \mathrm{cfu}$ of $S$. aureus Wood 46 (from an initial inoculum of $5 \times 10^{6} \mathrm{cfu}$ ) bound to collagen after bacterial growth in a serum-containing medium; among other proteins, the medium contained soluble fibronectin. In contrast, the adherence to collagen of bacteria grown in a fibronectin-depleted serum was reduced to $15 \%$ of the above-mentioned values. Finally, bacteria grown without serum did not bind to collagen at all. Thus, only fibronectin-containing medium could promote the adherence of $S$. aureus Wood 46 onto collagen-coated wells.

We have examined the role of several monosaccharides as potential inhibitors of the adherence of $S$. aureus Wood 46 to fibronectin-coated PVC and evaluated the contribution of sugar moieties, located at the bacterial surface, to adherence. The monosaccharides we used have previously been shown to be the components of heteropolysaccharides secreted by bacteria from different species. As shown in figure $2, \boldsymbol{\beta}$-methylgalactoside, $\mathrm{N}$-acetylglucosamine, $\alpha$-methylgalactoside, and $\alpha$-methylmannoside produced a concentration-dependent inhibition of staphylococcal adherence to fibronectin-coated PVC, although maximal inhibition with these monosaccharides was observed only at a final concentration of $200 \mathrm{mM}$. In contrast, fucose produced a similar inhibition at a much lower concentation $(20 \mathrm{mM})$.

\section{Discussion}

Fibronectin and collagen are the most thoroughly studied factors promoting cell adherence in vivo and in vitro [1]. Bacterial cells such as staphylococci and streptococci 


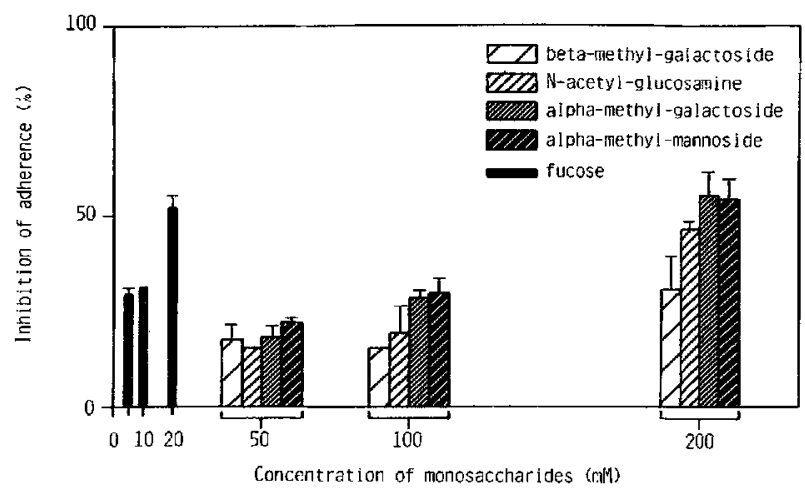

Figure 2. Dose-response monosaccharide inhibition of $S$. aureus Wood 46 adherence to fibronectin. The inhibition of adherence in the presence of sugars is compared with adherence in the absence of sugars. The results are the means ( \pm SD) of eight experiments.

have binding sites on the fibronectin molecule, but the type of interaction at the molecular level remains to be studied $[2,11]$. Some information regarding fibronectin as an adherence factor is nevertheless available: in an animal model [4], fibronectin was shown to mediate the attachment of $S$. aureus Wood 46 to an implanted biomaterial. Fibronectin at the surface of epithelial cells [11] or bound to a solid phase [3] promotes streptococcal [11] or staphylococcal [13] attachment.

We developed an in vitro system to study the role of host and environmental factors on the adherence properties of $S$. aureus Wood 46. This system allowed us to test the effect of potential inhibitors on the adherence of this strain to fibronectin-coated PVC, a biomaterial widely used for intravenous catheters, which are known to be susceptible to staphylococcal colonization and infection. As already shown for adherence to polymethylmethacrylate [3], bacterial adherence to PVC was promoted by fibronectin. Under our experimental conditions, maximal adherence of $S$. aureus Wood 46 to PVC was observed at a concentration of $50 \mu \mathrm{g}$ of fibronectin/ml. Because adherence of this strain to collagen was reduced to $15 \%$ of the initial values after bacterial growth in a fibronectin-depleted serum, we suggest that $S$. aureus Wood 46 does not adhere directly to collagen but indirectly by means of the intermediary linking property of fibronectin. Our results also showed that $\beta$-methylgalactoside, $N$-acetylglucosamine, $\alpha$ methylgalactoside, and $\alpha$-methylmannoside, but not $D$ glucose or D-mannose, competitively inhibited adherence of $S$. aureus Wood 46 to fibronectin-coated PVC. These effects on bacterial adherence were dose-dependent $(50 \%$ inhibition, $200 \mathrm{mM}$ ). Fucose was more inhibitory than the other sugars tested, because maximal inhibition was observed at $20 \mathrm{mM}$. This observation indicates that some surface components of $S$. aureus Wood 46 have specific- ity for fucose and thus may play a role in the adherence of this strain to a fibronectin-coated surface. Our results agree with the concept that sugar-containing molecules at the surface of bacteria may play a role in their adherence properties to a surface [11-14].

In conclusion, our study has confirmed and extended to another biomaterial (PVC) the role of fibronectin in the adherence of $S$. aureus Wood $46[3,5]$. Using various monosaccharides, we conveniently analyzed the inhibition of $S$. aureus adherence to surface-bound fibronectin. Our results suggest a role for carbohydrate-containing surface components of $S$. aureus as possible mediators of bacterial adherence to fibronectin-coated PVC. These results may contribute to a better understanding and prevention of intravenous catheter-induced infections.

Maria Inés Velazco, Francis A. Waldvogel Division of Infectious Diseases, Hôpital Cantonal Universitaire, Geneva, Switzerland

\section{References}

1. Yamada KM. Cell surface interactions with extracellular materials. Annu Rev Biochem 1983;52:761-99

2. Kuusela P. Fibronectin binds to Staphylococcus aureus. Nature (London) 1978;276:718-20

3. Vaudaux PE, Waldvogel FA, Morgenthaler JJ, Nydegger UE. Adsorption of fibronectin onto polymethylmethacrylate and promotion of Staphylococcus aureus adherence. Infect Immun 1984;45:768-74

4. Zimmerli W, Waldvogel FA, Vaudaux P, Nydegger UE. Pathogenesis of foreign body infection: description and characteristics of an animal model. J Infect Dis 1982;146:487-97

5. Vaudaux P, Suzuki R, Waldvogel FA, Morgenthaler JJ, Nydegger UE. Foreign body infection: role of fibronectin as a ligand for the adherence of Staphylococcus aureus. J Infect Dis 1984;150:546-53

6. Espersen F, Clemmensen I. Isolation of a fibronectin-binding protein from Staphylococcus aureus. Infect Immun 1982;37:526-31

7. Rydén C, Rubin $K$, Speziale $P$, Höök $M$, Lindberg $M$, Wadström T. Fibronectin receptors from Staphylococcus aureus. J Biol Chem 1983;258:3396-401

8. Costerton JW, Irvin RT, Cheng K-J. The bacterial glycocalyx in nature and disease. Annu Rev Microbiol 1981;35: 299-324

9. Peters G, Locci R, Pulverer G. Microbial colonization of prosthetic devices. II. Scanning electron microscopy of naturally infected intravenous catheters. Zentralbl Bakteriol Mikrobiol Hyg [B] 1981;173:293-9

10. Christiansen GD, Simpson WA, Bisno AL, Beachey EH. Adherence of slime-producing strains of Staphylococcus epidermidis to smooth surfaces. Infect Immun 1982; 37:318-26

11. Alkan M, Ofek I, Beachey EH. Adherence of pharyngeal and skin strains of group A streptococci to human skin and oral epithelial cells. Infect Immun 1977;18:555-7

12. Ofek I, Mirelman D, Sharon N. Adherence of Escherichia 
coli to human mucosal cells mediated by mannose receptors. Nature 1977;265:623-5

13. Franson TR, Sheth NK, Rose HD, Sohnle PG. Quantitative adherence in vitro of coagulase-negative staphylococci to intravascular catheters: inhibition with D-Mannosamine. J Infect Dis 1984;149:116
14. Collins-Lech C, Kalbfleisch JH, Franson TR, Sohnle PG. Inhibition by sugars of Candida albicans adherence to human buccal mucosal cells and corneocytes in vitro. Infect Immun 1984;46:831-4 